\author{
Proceedings of the $10^{\text {th }}$ International Conference on Applied Informatics \\ Eger, Hungary, January 30-February 1, 2017. pp. 137-144 \\ doi: $10.14794 /$ ICAI.10.2017.137
}

\title{
Modern environment inspired education
}

\author{
Zoltán Illés, Viktória H. Bakonyi, Jnr. Zoltán Illés \\ ELTE IK \\ zoltan.illes@elte.hu, hbv@inf.elte.hu, ilzo.inf.elte.hu
}

\begin{abstract}
During the last few years we have noticed very quick and dynamic technical evolution. Thanks to widening global internet access we are under continuous pressure by multimedia and information stream. It means that all the time, all over the day everybody holds his mobile devices and actively uses it.

In educational institutes the situation is the same during a lecture and during the practice hours too. Therefore the students' attention is diffused since it is divided between the subject and other multimedia streams. We state that we can increase the effectivity of teaching and the whole education process, lectures and practices by using the latest software and hardware technologies. In this paper we shall present our idea how to reflect the continuous changing environment in our teaching practice to increase the students' motivation.
\end{abstract}

Keywords: education, informatics, technology

MSC: 97B40, 97Q50, 97Q60

\section{Introduction}

Citing Heraclitus No man ever steps in the same river twice, for it's not the same river and he's not the same man. It was true more than 2500 years before and today it is true even more! Previously there was not such a big gap between the life style of the different generations as nowadays. The very quick technological development changed everything around us within some decades. This quick development which effected to everybody's daily life as well started with the appearance of PC-s in the 60th. It became quicker with the spread of public internet usage in the 90th. Soon this period was followed by the general usage of mobile phones and devices from the 2000th.

"Over some period of time, all the modern electronic devices have appeared in education gradually, and also the mobile phone, tablet, smartphone as well, they want to take their place in it." [1] 
Now the developing is quicker than any time before; we are in the middle of an internet connected world, the world of IoT with smart homes, smart cars, with wearable smart devices etc. as we are noticing today everything around us is smart. So after all, our need is not less than to have smart classrooms, smart education. The only remaining question is what you mean under these notions, what functionality you imagine behind it.

\section{Smart classes, auditoriums and a new type of ed- ucation}

In the last few years there are a growing number of universities which invested a huge amount of money to install most modern technology in their auditoriums and classrooms like the California University. Three levels of smart rooms are classified due to the technology built in (digital podium, interactive white boards, touch screens, voting systems, tablets, microphones, web cameras etc.). (http: //bit.1y/2iRwqtz)

These devices are used to record the lectures, to show any type of presentations, videos, to zoom on the questioning student, to ask their anonymous opinions through a voting system etc. As all of us know technology is not everything! There should be a well-trained teacher who knows what to do with these possibilities to create the most inspired environment for the students.

What is the most inspired environment? We focus on two different topics:

- To implement new technology based tools for modifying, modernizing the learning environment

- To modify the learning content with the newest possibilities like IoT devices and their programming.

\subsection{Modern applications to produce a new type of learning environment}

We researched the new learning habits of the students and identify the problematic points of it.

- It is not a newfangled problem, that university lectures are not really effective ways of learning. In the 1960th E. Dale examined the efficiency of different learning methods and he measured that we should use active learning methods to get better results. Traditional lectures are typical passive learning methods. Therefore it should be one of the reasons for emptying auditoriums. Do we have to stop giving lectures because there are no useful at all?

- The always available internet itself changed the learning attitude of the students, because they often could find ready-made answers for the typical general questions - so they did not have to make efforts to get the result. General 
question type is, how to convert a character into number in a programming language. Meanwhile the important question starts with sketching of a problem: to understand it, to analyze it, to give a suggestion for a solution and to define an architect - there is no solution in the net for all this! They felt that there is no need to go and listen to a lecture because they can download it later. (It may be the other reason of emptying auditoriums.) But after some years of teaching experience we have to state that it is not working really efficiently, contrary to the new possibilities the students' results are not better even worse than before! [2] Frequently they procrastinate the work for the last minute. We all know that to understand deeply something and to be able to use it later needs time and personal experiences, practices - without it somebody may understand it and pass the exam but forget everything soon. (That is why usually there are sub-deadlines within e-learning courses as well.) Do we have to forbid the usage of internet during the learning hours?

- Due to the internet usage Youngers accustomed to use different types of social networks to get help, to gather new information and to be in contact with each other. But we see that using social networks like Facebook may be addictive and besides its benefits it can be harmful as well. They are following the posts all day even if they are not really interesting ones, they do not want to miss anything. The reason of it is examined by the experts but now we are interested only in the fact. While the students always surrounded by smart mobile devices during they learning time as well, they continuously stops for a moment to read the new posts. Therefore they change the object of their attention very rapidly among different things (learning, social networks, music, youtube etc.) - it is called hyper attention - but the efficiency of learning becomes weaker. [7] To say a metaphor it is very likely to an interrupt in the case of an operating system: when a new interrupt arrives (post), the OS has to save everything (thoughts in connection with learning), then works with the new task (read the post) and after finishing it reload the old task and execute it (continue learning). This process needs extra time and maybe in the case of a human being the 'reload' will not be perfect. Do we have to forbid the usage of smart devices in schools and let them only in leisure time?

- Today the students' expectations are to be surrounded by the most modern technology in classrooms as well. If something is not the newest brand than that is not 'cool' so they do not enjoy it. Even more it is the situation at programmers' trainings, where they are interested only in the top newness. They lose their attendance and motivation if the projects they have to implement is not so up-to-date. The need for modern technology, software technology is required where complete, classical programming tools (like classes) are out of date. A development tool creates the code and hides a lot of details before the programmer. Meanwhile with the appearance of IoT programmers ${ }^{6}$ do have to know very low language possibilities, machine language too. Do we 
have to use only the modern high level programming languages?

- Today there are a lot of courses attended by several hundreds of students and it is impossible to remember their names, their successes and their problems; so personal attention is missing from the learning process. Do we have to throw away the idea of personal care?

We have put a lot of questions, from which you may think that we want to stop the technological development and we want to go back to the 19th century. Oh, no we do not want this, we would like to modernize university education.

\subsubsection{Our declared aims based on the result of the research}

Instead of

- forbidding the usage of smart phones in school we want to use their beloved devices to motivate them better in learning.

- forcing them to sit down and just listen to the lecturers we want to activate them during the lectures to take part in it interactively. [6]

- blaming social networks in vain we want to create an educational environment which is similar to social networks.

- accepting that there is no more personal attention we have to get new methods to fulfill this need.

- insisting on console applications with the beginners on PC-s (where they are used to colorful graphical UI), we want to show them the bases of programming on the newest platform, on microcontrollers where the UI is simply.

We must not rest on our laurels, let us start to work not to drop behind finally!

\subsubsection{Towards the realization of our concept}

In 2015 and 2016 we researched the possibility of using mobile devices in education and mobile development in a bilateral Slovakian-Hungarian tender. [5] According to the results we implemented a tool which will be able to prove our concept. The server program itself is a mobile optimized real-time web-application, a bi-directional presentation manager which checks user authentication and stores data. For the client units we use students' smart devices, as a BYOD system (Bring Your Own Device). This application is able to send real-time questions to the client devices and to receive the answers. Its working mechanism is the same as a ready-made voting system. The newness of it is, that students may also send questions to the teacher who may react to them immediately. (To avoid disturbing moments the educator is advised to use the application in presenter mode. See on Figure 1 We started the public testing of the base application in 2016 during the autumn semester therefore we are at the very beginning of the evaluation. We are 


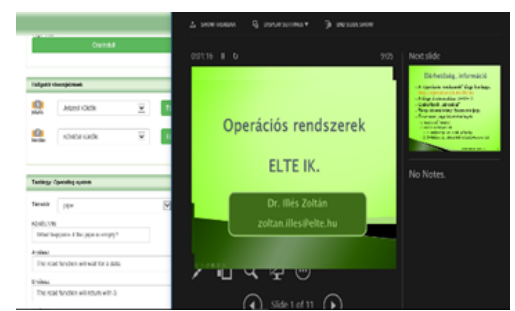

Figure 1: Election system

to give new features to it time-to-time by collecting new ideas with monitoring the real working of the system. The wished benefits of the tool are:

- To break the monotony of just listening to the lecture. 90 minutes is too long to pay attention to a monologue (lecture) - you should use some demo programs or anything else witch can help this problem. Vary your teaching methods!

- To force students to use the new information to solve a problem, to think about the topic actively. Active learning methods gives more efficient results referring to Dale's Learning Pyramid.

- To get real-time feed-backs from the students to fine-tune the deepness of the explanations and the chosen examples on the spot or to deal with the problem later during the practice courses. If something is not clear for the students the next steps will be more difficult. The aim is to go further only in that case, if they understand the base concepts.

- To encourage them to ask just in time when they don't understand something. Sometimes they think, that everybody else understands it and they are shying to ask or simply they do not want to disturb the lecture. With the usage of this system everything from the previously mentioned problems may be avoided.

- To make them feel that their opinion is important in the learning process and motivate them with it. Their answers or suggestions can be valued in real-time. They can get immediate feed-backs about their thoughts if it was good or where was the mistake in it. [3]

- To get a lot of information about the actual knowledge and the progression of it from each of the students and to use this information to give personal help in learning. In an auditorium with several hundreds of students the lecturer is not able to carry it out, but later in classrooms with 20 students the laboratory teacher has a better chance to give personal attention to everybody knowing their problems during the lectures. 
- To offer possibility for the students to measure their knowledge continuously comparing to others as well with continuous feed-backs on which topic do they have to work more. Long time ago (some decades) students knew each other and they could compare their knowledge easily to others. Nowadays it is forbidden to publish the grading of them due to the personal rights. Our tool may help them in it too.

\subsubsection{System testing experiences}

There are three different, separated phase in each research or product development.

1. The exploration of a topic, a problem which results a suggestion to the solution.

2. After the research phase the system has to be specified and the further task is to implement a test version.

3. Finally after the implementation it is required to collect the feed-backs, to analyze them and to modify the application according to the results. It is called life-cycle in the general world of problem solving.

In our case we are at the 2. phase and the late autumn test revealed some problematic points listed below:

1. According to the architecture the client side uses jQuery code to connect to the server hub. During the implementation we did not aim to use as minimal jQuery functionality as possible. The result of it was that some of the students defined a task for themselves to modify the client side code. Anyway we must modify this, because it offers a hacking possibility for the students which is contrary to our aims.

2. In this moment the good answer is only presented by the teacher, the feedback is not shown on the client devices.

\subsection{Next step towards inspiration}

Students usually use the latest technology and the newest version of applications on their own personal devices and they lose their attention and motivation if the projects they have to implement is not so up-to-date. We have been always solicitous for the appearance of new technologies in our subjects. It is very important to motivate programmers with teaching the most modern programming methods and paradigms but maybe it is more important to motivate future informatics teachers not to be satisfied with the old solutions but to teach them to search always for new possibilities. But nowadays we have several very good reasons to deal with microcontrollers, the bases of IoT (Internet of Things) world. 


\subsubsection{The aimed benefits of using microcontrollers}

- To understand the working of computers is easier to deal with much simple devices. If somebody uses e.g. Windows operating system and click on an icon - what happens in the background. Using e.g. Arduino there is no OS (Operating System) the result of the written code is the result, nothing hides the substance.

- To use a microcontroller the students may study the features of real-time applications. The importance of real-time programs and OS are growing nowadays, but a parallel system is too complex for the first sight.

- To use a microcontroller with some sensors students have to work with physics and informatics knowledge together. Nowadays there is no strict border between programming informatics and engineering informatics and everybody has to get some impression about this.

- To build a small system using some devices will help to explain the more complex systems like smart cars, smart buildings, smart cities, which are public notions today. It is especially important for future informatics teacher to be able to present it to the children and explain it to them!

- To create an IoT system from several microcontrollers and sensors may modify our environment into a smart one. We may bring to existence some kind of smart classroom too.

- To propose some meaningful project work is easier with using some sensors. Active learning is more efficient than passive one. The benefit of collaboration is preferable. [8]

\subsubsection{The plan: The bridge between microcontrollers and smart phones}

As we can see IoT tools take us very close to the possibilities of ready-made manufacturing. Using the boards and the connected components we may easily create an IoT solution. Using such a smart board with its breadboard it is very easy to create a plan and build the required prototype. If the prototype building is successfully tested and it gives the required result than the solution is ready to manufacture and we can give a task to an electrical engineer to create the miniaturized final circuits. So we can make the required IoT development much quicker than before, when there was an electrical engineer at each step of the process. These intelligent endpoints, intelligent local controllers can work on local tasks successfully but from our point of view we need their later managing, modifying, controlling. Today these devices are not so closed systems as a refrigerator or a washing machine. We have to answer the question how we can grant a general interface to these IoT endpoints. According to our research our answer is BYOD- we have to define an interface which can be connect from anywhere (laptop, mobile phone etc.) to this endpoint. We need a universal communication method which fits to the need of IoT world. 


\section{Summary}

David Willets (ex-minister UK) said The days where the academic experience is simply sitting in rows with 500 other people taking notes from slides on a screen that you can access online on your lap top, universities now have to do far better than that. http://bit.1y/1ntkoDX

According to our researches we created a concept how to change our teaching methods and the teaching content as well due to the very rapidly changing technology. Therefore we implemented a new tool for activate students and make the lectures interactive ones. In the moment of writing this paper we do not have enough data to verify our concept we need some correction due to the testing results. Our next focus point is the usage of microcontrollers, sensors and IoT systems hoping that our students will enjoy education due to the inspiring environment.

\section{References}

[1] PŠenÁková, I., Szabó, T., Internet mint médium az oktatásban In: 1. IKT az oktatásban : Konferencia Újvidéki Egyetem Magyar Tannyelvü Tanítóképzố Kar, Szabadka 12. április 2014. - Subotica : Újvidéki Egyetem, 2014. - ISBN 978-86-8709543-4, S. 228-236.

[2] Dr. Illés, Z., Jnr. Illés, Z., H Bakonyi, V., Dr. Psenák, I., Dr. Szabó, T., Dr. Zitny, R., Az MMM-generáció és az oktatás, VII. Oktatás-Informatikai Konferencia: Tanulmánykötet. Konferencia helye, ideje: Budapest, Magyarország, 2015.05.15-2015.05.16. Budapest: ELTE PPK Neveléstudományi Intézet, 2015. pp. 53-54. (ISBN:978-963-284-598-2)

[3] BÁвosık, I., Neveléselmélet, Osiris kiadó 2004 963-389-655-X, IV Chapter, 6.2 (Online). Available: http://bit.1y/1sVEDTz [Accessed on: April. 20, 2017].

[4] Dr. Illés, Z., H Bakonyi. V., Jnr. Illés, Z., Valós időben, valós világban, InfoDidact 2016 Paper 17. 6 p. (ISBN:978-963-12-3892-1)

[5] Dr. Illés, Z., H Bakonyi, V., Mobile driven Changes in Education, Edukacja Technika Informatyka / Education Technology Computer Science 11:(1) pp. 310-315. (2015))

[6] H. Bakonyi, V., Dr. Illés, Z., Interactive talks, Edukacja Technika Informatyka / Education Technology Computer Science 11:(1) pp. 298-303. (2015)

[7] Dani, E., E-létezés és „hiperfigyelem”, In: Könyv és Nevelés 2013/4 (Online) Available: http://bit.1y/10sFALM [Accessed on: April. 20, 2017].

[8] Prince, M., Does Active Learning Work? A Review of the Research In: Journal of Engineering Education 2004, (Online) Available: http://bit.1y/1sjNRZ7 [Accessed on: April. 20, 2017] 